\title{
Pro Se Litigation: Is This Phenomenon Helping Or Hurting Our Legal System?
}

\author{
Dean A. Frantsvog, Minot State University, USA
}

\begin{abstract}
As we have seen over the last two decades, the number of lawsuits in America is rising significantly. We have become an increasingly litigious society. In the past, it was extremely uncommon for someone to go to court without a lawyer. However today, for a variety of reasons, this is becoming commonplace. This trend brings with it some unique challenges to the legal field. While representing oneself may ensure that you "get your day in court" the problems associated with this choice might outweigh any benefit. This paper examines this serious and ever expanding phenomenon in the legal field. Correctly framing the issue and its possible repercussions can only help in finding the proper way to ensure that all litigants are treated fairly in our justice system. This paper helps lay out the issues and examines some possible solutions.
\end{abstract}

Keywords: pro se, lawyers, court system; litigation; legal costs; and judges

\section{INTRODUCTION}

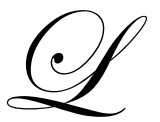

itigants who choose to forego representation from an attorney and represent him or her-self in court are called "pro se" litigants. "Pro se" is a Latin term meaning "for him-self". ${ }^{1}$ Pro se litigation has occurred since the beginning of our country, with its beginning stemming from British common law. The United States Constitution and its Sixth Amendment give Americans their right to pro se litigation. ${ }^{2}$

Pro se litigation is becoming more common as the number of unrepresented litigants in the justice system is increasing. ${ }^{3}$ Many reasons can be given as to why the number of pro se litigants is rising. Meanwhile, researchers and professionals are trying to figure out what can be done to help those involved with pro se litigation. What we do know is that pro se litigation has created some obstacles for everyone in the justice system, especially lawyers. In exploring this trend, we can explain further why the number of pro se litigants is increasing, why pro se litigants cause problems in the justice system, how professionals can assist pro se litigants and how everyone involved can deal with the problems that accompany pro se litigation.

\section{INCREASING NUMBER OF PRO SE LITIGANTS}

Why is the number of pro se litigants in the justice system is increasing? Possible explanations for the increasing number of pro se litigants vary from study to study. There are, however, a few key demographics that keep showing up when looking at self represented litigants. A study done by John M. Greacen for the Summit on the Future of Self-Represented Litigation found that:

\footnotetext{
${ }_{1}^{1}$ American Bar Association. Manual for Pro Se Litigants Before the Federal Board of Contract Appeals. 1 (2002).

2 The Sixth Amendment to the United States Constitution states: "In all criminal prosecutions, the accused shall enjoy the right to a speedy and public trial, by an impartial jury of the State and district wherein the crime shall have been committed, which district shall have been previously ascertained by law, and to be informed of the nature and cause of the accusation; to be confronted with the witnesses against him; to have compulsory process for obtaining witnesses in his favor, and to have the Assistance of Counsel for his defense."

${ }^{3}$ Gibeaut, John, Turning Pro Se: ABA Journal, 85(1) January 1999, 28.
} 
1. The vast majority, but not all, self-represented litigants are poor or of limited means.

2. Most have a high school education

3. A large majority are women

4. A majority are young

5. The most usual reasons given for not having a lawyer are, in order:

a. inability to pay for a lawyer

b. the matter is not complicated enough to require a lawyer

c. the litigant doesn't want to pay the cost of a lawyer, and

d. The case will get resolved more quickly without a lawyer. ${ }^{4}$

Another explanation to why individuals seek to represent themselves in court is because they may have been advised to do so. In today's "do it yourself" world, all one has to do is turn on the television and you will be inundated with commercials leading you to websites that will help you handle all of your legal problems. These websites can "help" you create a will, start a new corporation, draft complex contracts, get a divorce and many other legal matters. Or, if you are not computer savvy, you only need to go to the local office supply store to pick up real estate deeds, form contracts and shareholder agreements. The accessibility to these legal documents is at an all time high.

In the U.S. Court of Appeals for the Fourth Circuit, more than fifty percent of all appeals have been filed and prosecuted by litigants without lawyers. This has been the highest of all of the circuits, as the national average is about 43 percent of cases. ${ }^{5}$ While pro se litigation at the Small Claims Court level is common and most likely encouraged, when litigants begin representing themselves in complicated matters at the state's highest courts and on the federal level, the possibility of problems increase dramatically.

\section{WHY PRO SE LITIGATION IS A PROBLEM}

Many people may criticize the rise of pro se litigants by saying it is a problem. Is it right to call it a problem if Americans are given the constitutional right to self-represent? As Americans, we do not want our rights jeopardized, so deciding how much criticism is acceptable is part of the controversy of pro se litigation. Regardless, a lawyer opposing a pro se litigant may agree with the criticism.

Opposing a pro se litigant may bring additional obstacles for the opposing lawyer. Some Lawyers that have dealt with pro se litigants may say that pro se litigants don't know or follow court rules, don't understand or obey the law, and that judges may give them unfair leeway. It can be said that these problems may be damaging the legal profession itself. Everyone in the court is affected by a self-represented party, but how a lawyer has to deal with a pro se litigant may be very difficult.

The pro se litigant has chosen to deal with the obstacles that arise with self-representing in court, but the opposing lawyer is given no option but to deal with the issues that accompany a pro se litigant. Pro se litigants may cause an additional burden on the opposing party, such as procedural delays, increased court time, and the costs associated with delayed court time. ${ }^{6}$

Besides creating problems for opposing lawyers, pro se litigation also presents ethical issues that have to be dealt with by the whole court. The goals of the court are to remain as neutral as possible when making a decision, protecting the rights of the debtors, and making sure the judgment creditors stay within the law. ${ }^{7}$ Judges run their courtroom and can freely allow a rule or procedure to be flexed. This is their right and in their discretion. Does the

\footnotetext{
${ }^{4}$ Graecen, J. M. ,Framing the Issues for the Summit on the Future of Self-Represented Litigation. 19-26 (2005). Retrieved from www.ncsconline.org.

${ }^{5}$ Baldas, Tresa. $9^{\text {th }}$ Circuit feels Pro Se Pressure, National Law Review, (November 18, 2004).

${ }^{6}$ Tiffany Buxton, Foreign Solutions to the U.S. Pro Se Phenomenon, 34 Case Western Reserve Journal of International Law 103 (2003).

${ }^{7}$ Zorza, Esq., Richard. (2005) Paper 5: Changing the System so that Self-Represented Litigants Receive Compliance with Judgments and Orders: Where We Are and Where We Should Be Going [PDF Document]. In The Future of Self-Represented Litigation: Report from the March 2005 Summit, 59-68. Retrieved August 4, 2008, from www.nscsonline.org.
} 
judge have to change the rules for a pro se litigant? They certainly do not. As long as the judge allows the pro se litigant to represent his or her case fairly in court, the judge is pursuing his or her role correctly.

Pro se litigants have to be dealt with from the calendaring, to the records, to the hearings, and to the judges. Therefore, an opposing lawyer's response to a pro se litigant is very important. Pro se litigants can be perceived to have an unfair advantage over those who bring lawyers to court. They can be looked at very negatively. This perception comes from the fact that judges and opposing lawyers may have to alter their ways to accommodate the pro se litigant. Pro se litigants may not be required to play exactly by the rules like the represented party has to because they are not knowledgeable enough of the judicial process.

How far judges must or may go becomes an issue in accommodating a pro se litigant. No one will argue that a pro se litigant does not have the right to represent themselves. However, is there and should there be two separate and distinct sets of rules for those people who are represented by counsel and those who are not? Many times this level of accommodation depends upon nothing more than the judge who is handling the case. Certain judges may be inclined to help a pre se litigant a great deal, while others may see them as a distraction and yet another roadblock on an already crowded litigation docket.

A standard procedure for dealing with pro se litigants would be ideal, but legal professionals have yet have to agree on a standard way of accommodating pro se litigants. Some may agree that a standardized procedure should be set in place while others do not agree. The American Judicature Society has come up with several ways to react to the growing problems associated with pro se litigation. They are:

1. Standardized and simplified courtrooms

2. Rethinking how courts and technology can be changed to improve access

3. Defining the role of the judge in pro se litigation

4. Simplifying procedural and evidentiary rules

5. Redefining the role of attorneys and the $\operatorname{bar}^{8}$

With pro se litigation rising in popularity, individuals may have the idea that pro se litigation is easy. In order to help create fewer problems for the court and for the benefit of the pro se litigant, resources are available for individuals seeking to self-represent. Using available resources may smooth along the trial process for the pro se and the opposing attorney, as well as the rest of the court. Resources can help pro se litigants become more familiar with legal terms along with how the trial process works. Technology has been crucial to smoothing the litigation process by providing pro se litigants with more accessible information than ever. Web-based legal decision support, electronic filling, websites, and manuals are available for self-represented litigants. The American Bar Association's Pro Bono Committee has a manual that is available for pro se litigants that was created in $2002 .{ }^{9}$

\section{DECIDING HOW TO BEST DEAL WITH PRO SE SITUATION}

Should it be on the pro se litigant, the lawyers, or the court system to make self-representation less problematic? There is currently no set standard to assist pro se litigants in the courtroom. Thus, that is why committees and groups of legal professionals are forming to try to make this pro se situation as fair as possible for all involved. A standardized process would be beneficial to the court, allowing them to work faster because they will be familiar with the process.

The preamble to the American Bar Association's Model Rules provides guidance for a lawyer representing a party, but does not provide guidance for a lawyer representing a party that is opposing a self represented party. Only Model Rule 4.3 addresses the topic of dealing with an unrepresented party. Rule 4.3 reads:

\footnotetext{
${ }^{8}$ Kathleen M. Sampson, Meeting the Pro Se Challenge. 84 Judicature 326 (2001).

9 American Bar Association. Manual for Pro Se Litigants [PDF document]. (2002). Retrieved July 24, 2008, from Academic Search Premier Database.
} 
In dealing on behalf of a client with a person who is not represented by counsel, a lawyer shall not state or imply that the lawyer is disinterested. When the lawyer knows or reasonably should know that the unrepresented person misunderstands the lawyer's role in the matter, the lawyer shall make reasonable efforts to correct the misunderstanding. The lawyer shall not give legal advice to an unrepresented person, other than the advice to secure counsel, if the lawyer knows or reasonably should know that the interests of such a person are or have a reasonable possibility of being in conflict with the interests of the client. ${ }^{10}$

Rule 4.3 makes it clear that a lawyer representing a party cannot ignore an unrepresented litigant. The Rule makes it an affirmative duty to correct any misunderstanding or even potential misunderstanding that the unrepresented person may have. While this duty may seem small, by doing nothing in a case, the lawyer could find $\mathrm{him} /$ herself in violation of this duty. Further, if a lawyer goes too far in communicating with an unrepresented litigant and that communication could "reasonably" be misunderstood, that lawyer could again find him/herself in violation of the Rule.

The best practice in dealing with an unrepresented litigant is to communicate only on necessary matters and to make sure that no misunderstanding regarding representation could possibly occur. Picking up the phone and contacting opposing counsel on a simple matter may be quite different in dealing with an unrepresented litigant. This practice, and many others that we take for granted every day, will have to be changed so as not to cause any questions as to whether or not the lawyer was in violation of Rule 4.3 or any other governing rule. Since pro se litigant are becoming such a common occurrence in the legal field, dealing with their presence will change the way all lawyers handle this situation.

\section{CONCLUSION}

These ideas are only few of many ideas that can be implemented into today's justice system. Professionals are always creating new ways to deal with pro se litigation. They have one goal in mind, and that is to keep the justice system fair as possible for all involved. In order to accomplish this, judges must remain impartial while law clerks and lawyers must be careful to define the line between providing information and legal advice to litigants. If rules are drawn out clearly, the court system can follow it to ensure each party is getting unbiased treatment. These options are best if pro se litigation is going to keep increasing.

\section{AUTHOR INFORMATION}

Dean Frantsvog is an assistant professor of law in the College of Business at Minot State University in Minot, North Dakota. In addition to his teaching duties, Dean continues to work in the private practice of law. His main areas of legal practice are business and financial law. Dean's research interests are comparing how the practice of law is changing through technology and also bringing the courtroom and the classroom together.

\footnotetext{
10 American Bar Association, Model Rules of Professional Conduct, Rule 4.3, (2004).
} 